\title{
Kapasitas Memori Kerja dalam Pengambilan Keputusan
}

\author{
M. Dinah Charlota Lerik ${ }^{1}$ \\ Fakultas Kesehatan Masyarakat Universitas Nusa Cendana
}

\begin{abstract}
This paper will discussed the working memory model developed by Baddeley and Hitch. Baddeley's claimed that working memory consists of three components: the central executive and the two slave systems, the phonological loop and visuospatial sketchpad. The other model is created by Cowan, which assumes that working memory includes a number of processes that can keep a limited amount of information accessible for a limited amount of time. To test a person's working memory capacity, there have been many working memory span tasks. Few experiment will be discused about the amount of working memory load determines the heuristic by a person who make decision, determine the conjuction fallacy and judgment.
\end{abstract}

Keywords: conjunction fallacy, heuristic, judgment, span task, working memory

\section{Pengantar}

Salah satu keunggulan manusia adalah kemampuan untuk mengelola informasi secara mental dalam kondisi aktif dan ketersediaan akses, secara bersamaan seperti perencanaan, penalaran, pemecahan masalah, membaca, dan abstraksi. Tentu saja, beberapa orang melakukan tugas-tugas tersebut lebih berhasil dari pada orang lain.

Memori kerja merupakan metafora yang digunakan ahli psikologi kognitif untuk mendeskripsikan kemampuan mengelola dan memproses informasi yang relevan secara simultan dan bertujuan. Konsep memori kerja pada dasarnya merefleksikan sebuah bentuk memori, tetapi ini lebih dari sekedar memori, memori yang bekerja, untuk melayani proses kognitif kompleks. Memori kerja memiliki multikomponen, atau sebuah kumpulan proses inter-relasi, yang menyertakan beberapa

\footnotetext{
1 Korespondensi mengenai artikel ini dapat dilakukan melalui: mnendissa@yahoo.co.id
}

fungsi kognitif penting (Miyake \& Syah, 1999).

\section{Model Memori Kerja}

Model memori kerja mengasumsikan sistem kapasitas terbatas, yang mempertahankan informasi sementara dan mendukung proses pemikiran manusia dengan menyediakan titik temu antara persepsi, memori jangka panjang dan tindakan (Baddeley, 2000; 2003; Baddelely \& Hitch, 1974; Miyake \& Shah,1999). Dibandingkan dengan model-model lain tentang sistem penyimpanan jangka pendek (Atkinson \& Shiffrin, 1968), model memori kerja Baddeley menekankan kombinasi penyimpanan, pemrosesan dan perbedaan subsistem. Meskipun ada berbagai teori memori kerja (Miyake \& Shah,1999) sebagian besar teori-teori tersebut setuju pada kebutuhan akan sebuah sistem atensi berkapasitas terbatas, dilengkapi dengan sistem penyimpanan berbasis perifer (Baddelely, 2003).

Penulis akan memaparkan model memori kerja multi komponen yang 
dikembangkan oleh Baddeley (Baddeley \& Hitch, 1974) dan model Cowan yang lebih umum (Cowan, 1988). Kedua model tersebut berasumsi bahwa memori kerja berkapasitas terbatas dan berfungsi pada sejumlah tugas yang berdurasi waktu tertentu. Berikut ini adalah uraian beberapa perbedaan pada model Baddeley dan model Cowan. Model Baddeley. Model Baddeley mengklaim bahwa memori kerja terdiri dari tiga komponen: eksekutif pusat (central executive) dan dua subsistem, putaran fonologi (fonological loop) dan papan sketsa visuospatial (visuospatial sketcpath) (Baddeley \& Hitch, 1974). Tugas eksekutif pusat sebagai sumber daya memori yang dapat digunakan oleh salah satu sub-sistem. Eksekutif pusat bertanggung jawab atas bagaimana dan kapan kedua subsistem digunakan. Kemudian model Baddeley menjadi lebih rinci, eksekutif pusat digambarkan sebagai yang memiliki tiga tugas utama. Pertama memfokuskan perhatian seseorang pada tugas tertentu dan mencegah dari gangguan tugas lain. Kedua mengendalikan pembagian perhatian. Eksekutif pusat membantu seseorang ketika bekerja pada beberapa tugas dalam waktu yang bersamaan. Ketiga adalah switching (Baddeley, 2001), yaitu menentukan tugas berprioritas tinggi dan harus difokuskan pada suatu waktu tertentu.

Komponen kedua adalah putaran fonologi (Baddeley \& Hitch, 1974), bertanggung jawab atas pendengaran informasi yang sedang dikerjakan. Putaran fonologi mengulang informasi pendengaran supaya informasi tidak pudar dari memori kerja sebelum selesai digunakan. Pengulangan dalam putaran fonologi berupa pengulangan informasi berulang-ulang. Beberapa informasi tidak ditransfer dari memori kerja ke memori jangka panjang. Seseorang menjaga informasi secara online agar dapat digunakan, informasi harus diulang-ulang supaya tidak hilang. Jadi, putaran fonologi berfungsi menyimpan informasi verbal di memori kerja.

Conrad dan Hull (1964) menemukan, ketika kata-kata dalam daftar terdengar mirip, maka orang kesulitan merecall katakata secara akurat dalam urutan serial. Baddeley, Thomson, dan Buchanan (1975) juga menemukan ketika panjang kata-kata meningkat, para partisipan mengalami kesulitan merecall kata-kata dalam daftar. Semakin panjang sebuah kata, semakin sedikit waktu dapat diulang-ulang. Jadi, kata-kata yang kurang diulang-ulang lebih mungkin terlupakan.

Komponen ketiga adalah papan sketsa visuospatial (Baddeley \& Hitch, 1974). Komponen ini berfungsi menjaga informasi visual dan spasial dalam waktu terbatas. Papan sketsa visuospasial memungkinkan seseorang memanipulasi latar adegan dalam mental (Baddeley, 2001). Misalkan, seseorang bekerja secara mental pada soal pengurangan yang memvisualisasikan angka. Jika dihadapkan dengan operasi pinjaman angka, orang tersebut secara mental harus mengurangi salah satu dari digit di sebelah kiri dan menempatkan satu di depan digit sebelah kanan. Secara teoritis, kedua manipulasi dilakukan dalam papan sketsa visuospatial, tidak hanya angka dimanipulasi tetapi individu harus ingat semua manipulasi yang telah dilakukan sepanjang perjalanan masalah untuk memecahkan masalah secara akurat.

Baddeley, Grant, Wight, dan Thomson (1975) menemukan bahwa mengikuti sebuah objek secara visual berakibat pada penurunan kinerja pada tugas spasial lain. Namun, Brooks (1967) menemukan recall informasi spasial lebih terganggu oleh sebuah tugas visual lain dari pada sebuah tugas pendengaran. Studi ini membuktikan adanya sistem visual dan auditori dalam memori kerja, dan ketika dua tugas 
melibatkan subsistem yang sama terjadi defisit kognitif dari pada jika dua tugas dikerjakan oleh subsistem yang berbeda.

Ada beberapa pertanyaan tentang memori kerja yang tidak bisa dijawab oleh model multikomponen Baddeley (Baddeley \& Hitch, 1974). Seperti yang telah disebutkan sebelumnya, terdapat jumlah tugas atau stimulus yang terbatas yang dapat ditahan dalam memori kerja seseorang pada suatu titik waktu. Terdapat beberapa strategi untuk meningkatkan penyimpanan jumlah informasi dalam memori kerja pada titik waktu tertentu. Salah satu strategi adalah chunking. Seseorang dapat meningkatkan penyimpanan jumlah informasi dalam memori kerja, dengan menggabungkan beberapa potongan informasi individu menjadi satu, lebih kompleks, potongan informasi. Contoh, ketika seseorang diminta mengingat serangkaian angka, mungkin ia mencoba mengelompokkan nomor tunggal menjadi bilangan lebih kompleks, seperti tahun (misalnya, 1, 4, 9, dan 2 dapat digabungkan menjadi 1492). Konsep chunking tampaknya sangat dasar (misalnya Miller, 1956), model multikomponen tidak menjelaskan proses chunking (Baddeley \& Hitch, 1974). Chunking mengubah rangsangan yang lebih kompleks menjadi potongan-potongan informasi yang lebih mudah dikelola dengan menghubungkan informasi ke sesuatu yang sudah tersimpan di memori jangka panjang. Angka 1492 di atas bukanlah angka acak, tetapi tersimpan dalam memori jangka panjang sebagai tahun ketika Columbus berlayar dari Spanyol. Oleh karena itu, komponen lain memori kerja diperlukan untuk menjawab pertanyaan-pertanyaan tentang sistem memori kerja yang dapat mengambil informasi dari memori jangka panjang.

Komponen penyangga episodik (episodic buffer) ditambahkan ke model multi-komponen memori kerja kemudian
(Baddeley, 2001). Model Baddeley dan Hitch (1974) semula berasumsi masingmasing subsistem mempunyai penyimpanan berkapasitas terbatas dan eksekutif pusat bertugas mengontrol berapa banyak perhatian yang diterima sebuah tugas. Namun, tak satupun dari ketiga komponen ini berinteraksi dengan memori jangka panjang. Penyangga episodik tidak hanya menggabungkan informasi yang saat ini ada dalam memori kerja dengan informasi yang ada di memori jangka panjang, tetapi penyangga episodik juga berfungsi sebagai penerjemah sehingga informasi dalam dua subsistem dapat terintegrasi. Jadi, penyangga episodik mengintegrasikan informasi dalam putaran fonologi dan papan sketsa visuospatial.

Model Cowan. Model memori kerja Cowan (2000) lebih umum, berasumsi memori kerja tidak terdiri atas subkomponen tetapi, meliputi sejumlah proses yang dapat menyimpan informasi berjumlah terbatas yang dapat diakses untuk waktu terbatas. Temuan Cowan terdapat lebih banyak jenis informasi dari sekedar visuospatial dan auditori. Jadi, ada subsistem yang tidak terbatas, mungkin bisa berlaku untuk memori kerja, menghasilkan model memori kerja umum yang lebih tepat dibandingkan model multikomponen yang spesifik. Model Cowan (1988) menekankan dua jenis informasi utama dalam memori kerja yaitu informasi yang aktif saat itu di memori kerja dan informasi yang menjadi pusat perhatian. Ketika beberapa tugas sedang dikerjakan seseorang, maka terdapat beberapa potong informasi yang sedang digunakan dalam memori kerja. Bahkan jika seseorang memiliki beberapa potongan informasi dalam memori kerja pada satu titik waktu, hanya sebagian kecil dari informasi itu yang dapat difokuskan pada satu titik waktu itu. 
Potongan informasi yang aktif ada banyak dalam memori kerja, namun hanya beberapa potong informasi yang mendapatkan perhatian seseorang. Perbedaan utama model Cowan (1988) dan model Baddeley (Baddeley \& Hitch, 1974) adalah ide tentang fungsi khusus subkomponen tertentu pada model Baddeley tetapi tidak pada model Cowan. Studi tentang memori kerja telah menunjukkan bahwa stimulus lisan dan stimulus visual tidak menyebabkan banyak gangguan satu sama lain karena stimulus datang dari domain yang berbeda. Kurangnya gangguan ini ditafsirkan sebagai terdapat beberapa komponen dalam memori kerja. Reisberg, Rappaport, dan O'Shaughnessy (1984) melakukan studi di mana partisipan menggunakan jari-jari mereka untuk menyimpan informasi dalam memori kerja, menunjukkan orang dapat menggunakan jari-jari mereka untuk bekerja pada informasi memori kerja tanpa mengganggu informasi yang seharusnya ditahan oleh putaran fonologi atau papan sketsa visuospatial. Reisberg, et al. (1984) menemukan bukti tidak ada batasan jumlah subsistem dalam memori kerja. Sementara ada beberapa keraguan tentang subsistem dalam model Baddeley, model Cowan sangat umum dan tidak terlalu tendensius. Tulisan ini mengacu pada ide bahwa sumber daya terbatas menjadi karakteristik penting memori kerja. Oleh karena itu, tidak hanya melihat konstruk memori kerja yang lebih umum, perlu memperhatikan perbedaan individu dalam kapasitas memori kerja juga.

\section{Kapasitas Memori Kerja}

Barrett, Tugade, dan Engle (2004) menunjukkan konstruk kapasitas memori kerja mirip dengan fungsi komponen eksekutif pusat pada model memori kerja Baddeley (Baddeley \& Hitch,1974). Kapasitas memori kerja diukur dengan berbagai tugas rentang.
Tugas-tugas rentang yang dibahas berikut ini menguji kemampuan orang untuk memusatkan perhatian pada dua tugas pada satu waktu bersamaan. Aspek terpenting tugas rentang adalah pengolahan komponen setiap tugas harus interfer dengan rehearse komponen latihan (Conway, et al., 2005). Tugas-tugas bersaing mendapatkan sumber daya memori kerja, orang berkapasitas memori kerja lebih kecil akan menunjukkan defisit kinerja pada satu tugas, jika tidak kedua tugas dikerjakan pada saat yang sama, sementara orang berkapasitas memori kerja lebih besar akan menunjukkan defisit lebih sedikit dalam kinerja.

Tugas rentang operasi (O-SPAN, Turner \& Engle, 1989) merupakan salah satu versi tugas mengukur rentang kapasitas memori kerja. Peserta ditunjukkan soal matematika dan jawabannya; tugas peserta menentukan apakah jawaban itu benar untuk soal matematika tersebut. Setelah respons terhadap soal matematika, peserta ditunjukkan sebuah kata diakhir soal matematika dan serangkaian kata berpasangan, peserta diminta untuk mere-call masing-masing kata itu. Jumlah soal matematika dan pasangan kata dalam satu set bervariasi antara dua sampai enam pasangan per set. Unsworth, Heitz, Schrock, dan Engle (2005) memilih menggunakan ukuran set soal matematika dan kata pasangan bervariasi dari set ke set, adapun peneliti lain memilih untuk ukuran set meningkat, semakin bertambah sampai tugas berakhir. Manfaat dari format yang digunakan Unsworth, et al. (2005) adalah peserta tidak dapat memprediksi ukuran set berikutnya. Namun, tugas O-SPAN itu sulit dan dibangun berdasarkan ide bahwa orang memfokuskan perhatian pada dua tugas terpisah, jika orang itu memprediksi berapa banyak pasangan yang akan berada di set berikutnya maka mungkin ada tugas ketiga 
yang harus dikerjakan orang itu. Jadi, lebih masuk akal untuk tetap dengan format set disajikan secara semakin meningkat supaya hanya dua tugas yang bersaing untuk sumber daya memori kerja.

Tugas rentang membaca (R-SPAN, Daneman \& Carpenter, 1980) adalah salah satu tugas rentang memori kerja pertama. Peserta $R$-SPAN disuruh membaca kalimat secara keras dan diberitahu bahwa mereka diharapkan merecall kata terakhir dari masing-masing kalimat. Pada kesimpulan set itu, peserta merecall kata terakhir dari masing-masing kalimat. Jumlah kalimat semakin meningkat dari set ke set. Tugas rentang dibangun atas asumsi bahwa satu tugas melibatkan pengolahan informasi dan tugas lainnya mempertahankan informasi. Pada tugas R-SPAN ini, sulit mengetahui apakah peserta benar-benar memproses kalimat atau hanya membaca kalimat dengan keras dan hanya memperhatikan kata diakhir kalimat. Kemudian Daneman dan Carpenter (1980) membuat studi dimana peserta diminta memverifikasi validitas kalimat dengan menanggapi benar atau salah di akhir kalimat. Validasi komponen dalam eksperimen ini memastikan para peserta tidak hanya mengelola informasi tetapi juga memproses informasi secara bersamaan.

Pashler, Harris, dan Neuchterlein (2008) menyebutkan ketika bekerja pada beberapa tugas disaat yang sama, dapat terjadi bottleneck. Kasus bottleneck ini menyebabkan penurunan kinerja pada kedua tugas. Pashler, et al. (2008) menemukan ini juga terjadi dalam tugas membuat keputusan dalam Task Perjudian Iowa. Ditemukan pada blok percobaan tugas ganda, orang lebih lambat dalam membuat keputusan daripada di blok percobaan kontrol. Meskipun ada bukti orang-orang lebih lambat dalam membuat keputusan dalam uji tugas ganda dibandingkan uji kontrol, sifat tugas Perjudian Iowa membuat sulit untuk menilai akurasi orang ketika membuat keputusan dalam paradigma tugas ganda.

Memori kerja telah terbukti berhubungan dengan banyak konstruk lain di bidang psikologi, seperti dengan pemahaman (Daneman \& Carpenter, 1980) dan kecerdasan umum (Jensen, 1998). Hal ini menunjukkan bahwa konstruk yang melibatkan pemrosesan level tinggi seseorang juga terkait dengan konstruk kapasitas memori kerja. Brewin dan Beaton (2002) menemukan orang berrentang memori kerja tinggi lebih baik dalam menekan pikiran irrelevan dengan tugas yang sedang dikerjakan daripada orang berentang memori kerja rendah. Tugas rentang memori kerja pada dasarnya menguji kemampuan seseorang bekerja pada dua tugas di waktu bersamaan. Jadi, orang-orang berrentang memori kerja tinggi lebih baik mengerjakan beberapa tugas secara bersamaan dibandingkan orang berrentang memori kerja rendah.

Hasil penelitian Ashcraft dan Kirk (2001), Kane dan Engle (2000) menunjukkan kapasitas memori kerja seseorang memengaruhi kemampuannya untuk mengerjakan beberapa tugas di waktu bersamaan. Tugas rentang dibangun pada premis bahwa orang-orang berkapasitas memori kerja lebih besar akan lebih baik mengerjakan beberapa tugas di waktu bersamaan (Unsworth, et al.., 2005). Ketika seseorang bekerja pada beberapa tugas, tiap tugas membutuhkan sumber daya memori kerja, terjadi kompetisi sumber daya memori kerja. Semakin sulit tugas, semakin banyak sumber daya diperlukan (Ashcraft \& Kirk, 2001).

Penelitian yang dilakukan oleh Copeland dan Radvansky (2004) juga menunjukkan bahwa orang berentang memori kerja sedikit menggunakan lebih 
sedikit strategi ketika mengerjakan tugas penalaran dibandingkan orang berrentang memori kerja besar. Mengetahui bahwa orang berrentang memori kerja besar menggunakan strategi lebih rumit ketika mengerjakan tugas dari orang berrentang memori kerja kecil, Beilock dan DeCaro (2007) melakukan penelitian untuk menentukan perbedaan penggunaan strategi antara orang bermemori kerja tinggi dan orang bermemori kerja rendah dalam situasi dengan tingkatan tekanan bervariasi. Beilock, Kulp, Holt, dan Carr (2004) menggambarkan bahwa tekanan lingkungan dapat mengkonsumsi sumber daya memori kerja, yang akan menghasilkan tekanan dan tugas bersaing untuk sumber daya memori kerja. Beilock dan DeCaro (2007) menemukan ketika situasi tidak ada tekanan, orang berrentang memori kerja rendah menggunakan strategi sederhana sementara orang berrentang memori kerja tinggi menggunakan strategi yang lebih sulit. Sebaliknya, ketika ada tekanan situasi, baik peserta berrentang memori kerja tinggi dan peserta berrentang memori kerja rendah menggunakan strategi sederhana.

Eksperimen Copeland dan Radvansky (2004) menunjukkan ukuran rentang memori kerja seseorang mengindikasikan seberapa sulit strategi yang akan digunakan saat mengerjakan sebuah tugas. Eksperimen Beilock dan DeCaro (2007) mengindikasikan, ketika ada kompetisi untuk sumber daya memori kerja, orang berrentang tinggi melakukan tugas dengan cara yang sama dengan orang berrentang rendah. Oleh karena itu, ketika tugas tidak melibatkan kompetisi sumber daya memori kerja, orang ber-rentang tinggi dapat menggunakan strategi yang lebih kompleks daripada orang berrentang rendah. Namun, ketika ada kompetisi untuk sumber daya memori kerja, orang berrentang tinggi dan berren- tang rendah menggunakan strategi yang sama.

Daneman dan Carpenter (1980) berpendapat bahwa bukanlah ukuran memori kerja yang menunjukkan perbedaan dalam kinerja, tetapi efisiensi dalam pemrosesan stimulus. Dengan kata lain, perbedaan kinerja bukan ditentukan oleh jumlah ruang yang tersedia dalam memori kerja, tetapi pada seberapa efisien seseorang memproses stimulus dan tipe strategi yang digunakan untuk mengerjakan tugas. Orang efisien menggunakan lebih sedikit sumber daya untuk memproses tugas, sebaliknya orang kurang efisien menggunakan lebih banyak sumber daya untuk memproses tugas. Oleh karena itu, pengolahan efisiensi bisa menjadi alasan lain bahwa orang berkapasitas memori kerja lebih besar memiliki kemampuan untuk menggunakan strategi lebih rumit ketika mengerjakan tugas daripada orang berkapasitas memori kerja lebih kecil. Tulisan ini akan mengkaji memori kerja dan dampaknya pada kemampuan seseorang dalam membuat keputusan.

\section{Pembahasan}

\section{Pengambilan Keputusan dan Memori Kerja}

Studi bagaimana memori kerja memengaruhi kemampuan seseorang untuk membuat keputusan tampaknya belum meyakinkan. Namun, terdapat bukti hubungan beban memori kerja dan pengambilan keputusan. Seorang peneliti dapat memanipulasi beban memori kerja dengan berbagai cara. Hinson, Jameson, dan Whitney (2003) memanipulasi beban memori kerja dengan memvariasikan jumlah alternatif yang akan diukur saat peserta sedang membuat keputusan. Pada tugas ini, seseorang diberi pilihan antara mendapat uang sedikit sekarang atau uang banyak diwaktu kemudian. Semakin banyak alternatif yang 
tersedia, semakin tinggi beban memori kerja. Hasil studi ini, menunjukkan beban memori kerja meningkatkan impulsivitas peserta (lebih suka uang dalam jumlah kecil saat ini daripada jumlah uang lebih besar kemudian). Oleh karena itu, semakin besar sumber daya memori kerja yang dibutuhkan tugas, semakin besar kemungkinan orang bertindak impulsif. Whitney, Rinehart, dan Hinson (2008), menegaskan hal tersebut dan juga menemukan bahwa jumlah beban memori kerja yang dibutuhkan sebuah tugas menentukan heuristic, dimana orang akan memilih membuat keputusan yang menentukan seberapa impulsif keputusan itu.

De Neys (2006a dan 2006b) menemukan beberapa bukti yang menarik untuk peran memori kerja dalam pengambilan keputusan. Pada eksperimen De Neys '(2006a), peserta mengerjakan tugas penalaran silogisme, yang merupakan tugas utama paradigma tugas ganda (dual task); tugas kedua adalah tugas recall matrix dot di mana para peserta disajikan matrix dot sebelum silogisme dan kemudian harus menciptakan matriks setelah menjawab pertanyaan silogisme. Beberapa peserta tidak diberi tugas matriks dot (tidak berbeban), yang lain melihat matrix mudah (beban rendah), sementara yang lain melihat matriks sulit (beban tinggi). Peserta kelompok beban memori kerja rendah menunjukkan kinerja lebih baik pada tugas penalaran daripada peserta kelompok beban memori kerja tinggi. Juga, peserta dikelompokkan berdasarkan skor mereka pada tugas rentang operasi (O-span). Ditemukan kelompok rentang rendah menunjukkan penurunan besar dalam kinerja dengan beban tinggi daripada kelompok rentang tinggi. Pertimbangkan temuan Beilock dan DeCaro (2007), orang akan berpikir bahwa kelompok rentang tinggi akan menunjukkan penurunan kinerja lebih dalam dari kelompok rentang rendah. Dua hasil eksperimen mungkin berbeda karena untuk Beilock dan DeCaro, percobaan memanipulasi beban memori kerja sebagai variabel within subyek dan memanipulasi beban De Neys sebagai variabel between subjek.

De Neys (2006b) berusaha untuk mendapatkan pemahaman yang lebih baik ketika orang menggunakan pengambilan keputusan dengan sistem 1 yaitu pengambilan keputusan yang cepat, naluriah, dan emosional, dibandingkan dengan menggunakan pengambilan keputusan sistem dua yaitu pengambilan keputusan yang lebih lambat, lebih tenang dan berhatihati, serta lebih logis (Kahneman, 2012). Pada eksperimen pertama, peserta diberi pertanyaan serupa dengan permasalahan Linda sebagaimana pengambilan keputusan tugas-tugas lainnya. Permasalahan Linda adalah sebuah soal viggente yang digunakan oleh Tversky dan Kahnemman (1983) untuk membuktikan bahwa kebanyakan orang melakukan kesalahan dalam menjawab soal ini karena memakai heuristic (perhitungan mudah). Ditemukan peserta yang menjawab permasalahan Linda dengan benar (mungkin menggunakan Sistem 1) membutuhkan waktu lebih lama untuk memberikan tanggapan dari orang yang melakukan kekeliruan bersama (mungkin menggunakan sistem 2).

Eksperimen kedua dalam artikel ini memasangkan tugas pengambilan keputusan dengan tugas recall matrix dot (mirip dengan yang di De Neys 2006a). Satu kelompok peserta diminta untuk mengingat matriks yang rumit sedangkan kelompok lainnya diminta untuk mengingat matriks yanglebih mudah; oleh karena itu, beban memori kerja adalah faktor between subjek. Hasil studi ini menunjukkan semakin sulit tugas sekunder, semakin besar kemungkinan peserta menjadi korban kesalahan konjungtif (conjunction fallacy) yaitu 
kesalahan formal yang terjadi ketika diasumsikan bahwa kondisi tertentu lebih mungkin daripada satu kondisi umum. Pada eksperimen ketiga ini, peserta juga menjadi sasaran tugas rentang operasi $(\mathrm{O}$ span). Ditemukan kapasitas memori kerja berelasi positif dengan skor mereka pada permasalahan linda, menunjukkan bahwa semakin tinggi kapasitas memori kerja seseorang, semakin besar peluang memberikan jawaban benar pada masalah seperti permasalahan linda.

Eksperimen De Neys (2006a dan 2006b) memiliki beberapa implikasi. Artikel pertama (2006a) menunjukkan orang berrentang memori kerja tinggi, lebih baik di tugas penalaran dibandingkan orang berrentang rendah. Artikel ini juga menggambarkan jumlah sumber daya memori kerja yang dibutuhkan sebuah tugas memengaruhi seberapa baik performa seseorang dalam tugas penalaran. Artikel kedua (2006b) melihat pada kinerja peserta pada tugas pengambilan keputusan dengan menggunakan tugas klasik studi pengambilan keputusan. Ditemukan orang berkapasitas memori kerja tinggi kurang rentan terhadap kesalahan dalam tugas pengambilan keputusan. Hasil eksperimen ini juga menunjukkan jumlah sumber daya yang dibutuhkan untuk tugas itu memengaruhi performa tugas tersebut. Ditemukan pula, orang-orang dalam kelompok beban rendah membuat kesalahan lebih sedikit, sesuai dengan kesalahan konjuntive, daripada orang-orang dalam kelompok beban tinggi. Ditemukan kedua kelompok tidak berbeda dalam kapasitas memori kerja, oleh karena itu, perbedaan respons antara kelompok beban memori kerja adalah karena beban masalah dan bukan karena perbedaan kapasitas.

Ketika seseorang membuat keputusan dalam berbagai situasi, maka perlu membuat penilaian probabilitas. Dougherty dan
Hunter (2003) memberikan peserta daftar menu dan pesanan sekelompok pelanggan dari 32 menu selama74 hari. Kemudian peserta ditujukkan pelanggan tetap dan dipasangkan dengan item menu lalu diminta menilai kemungkinan menu yang dipesan orang itu. Kemudian, peserta ditunjukkan item menu, satu per satu, dan diminta untuk menilai berapa probabilitas menu itu akan dipesan. Sebuah penilaian menjadi subaditif jika jumlah probabilitas seseorang menyimpang dari seratus. Ini tugas pengambilan keputusan yang sulit, eksperimen ini menunjukkan seberapa baik orang dapat membuat penilaian probabilitas. Ditemukan kapasitas memori kerja berkorelasi signifikan dengan penilaian probabilitas, sehingga orang-orang berkapasitas memori kerja tinggi kurang subaditif (menyimpang kurang dari 100) dibandingkan orang berrentang memori kerja rendah. Seperti telah dibahas sebelumnya, banyak heuristik mengharuskan orang untuk membuat probabilitas penilaian. Oleh karena itu, kapasitas memori kerja berpengaruh pada kemampuan seseorang untuk membuat keputusan ketika menggunakan heuristik. Eksperimen kedua Dougherty dan Hunter (2003) meminta peserta membuat penilaian tentang kemungkinan berasal dari negara manakah orang itu, di bawah kondisi tekanan waktu yang berbeda. Peserta menggunakan pengetahuan tentang populasi negara untuk membuat penilaian. Ditemukan ketika tidak ada kendala waktu, korelasi tidak signifikan antara rentang memori kerja dan penilaian. Namun, korelasi ini signifikan ketika ada kendala waktu. Ketika tidak ada kendala waktu peserta melakukan cara yang sama seperti orang berrentang memori kerja rendah, tetapi ketika ada kendala waktu orang berrentang memori kerja tinggi menggunakan strategi lebih rumit daripada orang berrentang rendah. Hal ini bertentangan dengan temuan Beilock dan DeCaro (2007). 
Dougherty dan Hunter mendiskusikan hasil studinya, juga menunjukkan rentang memori kerja berdampak pada sejumlah alternatif yang dapat diperbandingkan ketika seseorang membuat keputusan.

Thomas, Dougherty, Sprenger, dan Harbison (2008) mendiskusikan kapasitas memori kerja menentukan batas atas alternatif yang dapat dikelola pada satu titik. Ketika banyak alternatif yang harus dianalisis untuk membuat keputusan, orang berrentang memori kerja tinggi memiliki keuntungan karena berkemampuan menganalisis lebih banyak pilihan daripada orang berrentang rendah. Salthouse (1992) menemukan korelasi negatif antara kapasitas memori kerja dan kecepatan pemrosesan, sehingga ketika kapasitas memori kerja meningkat, jumlah waktu yang dibutuhkan untuk memproses tugas menurun. Korelasi negatif ini menyiratkan orangorang berrentang memori kerja tinggi menghasilkan alternatif yang lebih daripada orang-orang berrentang memori kerja rendah. Karena itu, ketika ada keterbatasan waktu membuat keputusan, orang berentang memori kerja tinggi memiliki lebih banyak informasi untuk dimanfaatkan daripada orang-orang berentang memori kerja rendah.

\section{Penutup}

Kemampuan seseorang dalam membuat keputusan dipengaruhi oleh kapasitas memori kerjanya. Kapasitas memori kerja berpengaruh pada seberapa banyak item yang bisa tetap online di satu titik waktu dan memengaruhi jenis strategi yang digunakan saat seseorang mengerjakan tugas. Kapasitas memori kerja tidak hanya berdampak pada pengabaian informasi irrelevan, tetapi berdampak juga pada seberapa banyak tugas yang dapat dikerjakan seseorang secara bersamaan.

\section{Daftar Pustaka}

Ashcraft, M. H., \& Kirk, E. P. (2001). The relationships among working memory, math anxiety, and performance. Journal of Experimental Psychology: General, 130(2), 224-237.

Atkinson, R. C., \& Shiffrin, R. M. (1968). Chapter: Human memory: A proposed system and its control processes. In Spence, K. W., \& Spence, J. T. The psychology of learning and motivation (Volume 2). New York: Academic Press. pp. 89-195.

Baddeley, A. D. (2001). Is working memory still working? American Psychologists, 569-864.

Baddeley, A. D., \& Hitch, G. J. (1974). Working memory. In G. A. Bower (Ed.). The Psychology of Learning and Motivation, 8(00), 47-90.

Baddeley, A. D., Thomson, N., \& Buchanan, M. (1975). Word length and the structure of short-term memory. Journal of Verbal Learning and Verbal Behavior, 14, 575-589.

Baddeley, A. D., Grant, W., Wight, E., \& Thomson, N. (1975). Imagery and visual working memory. In P. M. A. Rabbitt \& S. Dornic (Eds.), Attention and performance V (pp. 205-217). London: Academic Press.

Baddeley, A. (2003). Working memory: Looking back and looking forward. Nature Reviews Neuroscience, 4, 829-839.

Barrett, L. F., Tugade, M. M., \& Engle, R. W. (2004). Individual differences in working memory capacity and dualprocess theories of the mind. Psychological Bulletin, 130(4), 553-573.

Beilock, S. L., Kulp, C. A., Holt, L. E., \& Carr, T. H. (2004). More on the fragility of performance: Choking under pressure in mathematical permasalahan 
solving. Journal of Experimental Psychology: General, 133, 584-600.

Beilock, S. L., \& DeCaro, M. S. (2007). From poor performance to success under stress: Working memory, strategy selection, and mathematical permasalahan solving under pressure. Journal of Experimental Psychology: Learning, Memory, and Cognition, 33, 983-998.

Brewin, C. R., \& Beaton, A. (2002). Thought suppression, intelligence, and working memory capacity. Behavior Research and Therapy, 40(8), 923-930.

Brooks, L. R. (1967). The suppression of visualization by reading. Quarterly Journal of Experimental Psychology, 19, 289-299.

Conrad, R., \& Hull, A. J. (1964). Information, acoustic confusion and memory span. British Journal of Psychology, 55, 429-432.

Conway, A. R. A., Kane, M. J., Bunting, M. F., Hambrick, D. Z., Wilhelm, O., \& Engle, R. W. (2005). Working memory span tasks: A methodological review and user's guide. Psychonomic Bulletin $\mathcal{E}$ Review, 12, 769-786.

Copeland, D. E., \& Radvansky, G. A. (2004). Working memory and syllogistic reasoning. The Quarterly Journal of Experimental Psychology: Human Experimenta Psychology, 57A(8), 14371457.

Cowan, N. (1988). Evolving conceptions of memory storage, selective attention, and their mutual constraints within the human information processing system. Psychological Bulletin, 104, 163-191.

Cowan, N. (2000). The magical number 4 in short term memory : A reconsideration of mental storage capacity. Behavioral and Brain science, 24, 87-185.

Daneman, M., \& Carpenter, P. A. (1980). Individual differences in working memory and reading. Journal of Verbal Learning and Verbal Behavior, 19, 450-466.

De Neys, W. (2006a). Working memory capacity and a notorious brain teaser: the case of the Monty Hall Dilemma. Journal of Experimental Psychology, 53, 123-131.

De Neys,W. (2006b). Dual processing in reasoning: two systems but one reasoned. Psychological Science, 17, 428433.

Dougherty, M. R. P., \& Hunter, J. (2003). Probability judgment and subadditivity: The role of working memory capacity and constraining retrieval. Memory $\mathcal{E}$ Cognition, 31, 968-982.

Hinson, J. M., Jameson, T. L., \& Whitney, P. (2003). Impulsive decision making and working memory. Journal of Experimental Psychology: Learning, Memory, and Cognition, 29(2), 298-306.

Jensen, A. R. (1998). The $g$ factor: The science of mental ability. Westport, CT US: Praeger Publishers/Greenwood Publishing Group.

Kane, M. J., \& Engle, R. W. (2000). Workingmemory capacity, proactive interference, and divided attention: Limits on long-term memory retrieval. Journal of Experimental Psychology: Learning, Memory, and Cognition, 26(2), 336-358.

Kahneman, D. (2012). Thingking, fast, and slow. London, England : Penguin Books.

Miyake, A., \& Shah, P. (1999). Model of working memory, mechanisms of active maintanance and executive control. New York, NY US: Cambridge University Press.

Pashler, H., Harris, C. R., \& Nuechterlein, K. H. (2008). Does the central bottleneck encompass voluntary selection of hedonically based choices? Experimental Psychology, 55(5), 313-321. 
Reisberg, D., Rappaport, I., \& O'Shaughnessy, M. (1984). Limits of working memory: The digit digit-span. Journal of Experimental Psychology: Learning, Memory, and Cognition, 203221.

Salthouse, T. A. (1992). Influence of processing speed on adult age differences in working memory. Acta Psychologica, 79, 155-170.

Thomas, R. P., Dougherty, M. R., Sprenger, A. M., \& Harbison, J. I. (2008). Diagnostic hypothesis generation and human judgment. Psychological Review, 115(1), 155-185.

Turner, M. L., \& Engle, R. W. (1989). Is working memory capacity task dependent? Journal of Memory and Language, 28, 127-154.

Tversky, Amos., \& Kahneman. (1983). Extension versus intuitive reasoning: The conjunction fallacy in probability judgment. Psychological Review, 90(4), 293-315. doi: 10.1037/0033-295X.90.4.293

Unsworth, N., Heitz, R. P., Schrock, J. C., \& Engle, R. W. (2005). An automated version of the operation span task. Behavior Research Methods, 37(3), 498-505.

Whitney, P., Rinehart, C. A., \& Hinson, J. M. (2008). Framing effects under cognitive load: The role of working memory in risky decisions. Psychon Bull Rev, 15(6), 1179-84. doi: 10.3758/PBR.15.6.1179. 